\title{
Prediksi Tingkat Risiko Penyakit Kardiovaskuler Aterosklerotik pada Pasien yang Berobat di Poliklinik Penyakit Dalam RSUP Prof. Dr. R. D. Kandou Manado
}

\author{
${ }^{1}$ Engelin E. Emor \\ ${ }^{2}$ Agnes L. Panda \\ ${ }^{2}$ Janry Pangemanan
}

\author{
${ }^{1}$ Program Studi Pendidikan Dokter Fakultas Kedokteran Universitas Sam Ratulangi Manado \\ ${ }^{2}$ Bagian Ilmu Penyakit Jantung dan Pembuluh Darah Fakultas Kedokteran \\ Universitas Sam Ratulangi Manado \\ Email: engelinemor@gmail.com
}

\begin{abstract}
Atherosclerotic cardiovascular disease is caused by the accumulation of plaque on the artery wall causing dysfunction of anatomical and hemodynamic system of the heart and blood flow. There are many risk factors that cause atherosclerotic cardiovascular disease which are divided into modifiable and unmodifiable risk factors. Prevention of this disease can be achieved with early detection, such as prediction the risk level of 10 years ahead of atherosclerotic cardiovascular disease by using the Framingham Risk Score (FRS). This study was aimed to obtain the risk level of atherosclerotic cardiovascular disease in patients at Internal Medicine Polyclinic of Prof. Dr. R. D. Kandou Hospital Manado by using their medical records from September to October 2017. This was a descriptive study with a cross sectional design. There were 100 samples obtained by using conclusive sampling technique. Of the 100 patients, $42(42 \%)$ patients had low risk, 27 (27\%) patients had moderate risk, and $31(31 \%)$ patients had high risk of atherosclerotic cardiovascular disease in 10 years ahead. Conclusion: In this study, the highest percentage was in patients with low risk, followed by patients with high risk, and moderate risk.
\end{abstract}

Keywords: ASCVD, Framingham Risk Score, Risk of atherosclerotic cardiovascular sisease.

\begin{abstract}
Abstrak: Penyakit kardiovaskuler aterosklerotik adalah penyakit yang disebabkan oleh adanya timbunan plak pada dinding arteri sehingga menyebabkan gangguan fungsional, anatomis serta sistem hemodinamis jantung dan pembuluh darah. Terdapat banyak faktor risiko yang menyebabkan terjadinya penyakit kardiovaskuler aterosklerotik yang dibagi menjadi faktor risiko yang dapat dimodifikasi dan yang tidak dapat dimodifikasi. Pencegahan penyakit ini dapat dilakukan dengan deteksi dini, salah satunya yaitu dengan memrediksi tingkat risiko 10 tahun kedepan terjadinya penyakit kardiovaskuler aterosklerotik dengan menggunakan Framingham Risk Score. Penelitian ini bertujuan untuk mengetahui tingkat risiko penyakit kardiovaskuler ateroskerotik pada pasien di Poliklinik Penyakit Dalam RSUP Prof. Dr. R. D. Kandou Manado. Jenis penelitian ialah deskriptif dengan desain potong lintang menggunakan data rekam medik pasien Poliklinik Penyakit Dalam RSUP Prof. Dr. R. D. Kandou Manado periode September Oktober 2017. Sampel penelitian berjumlah 100 orang dengan teknik pengambilan conclusive sampling. Terdapat 42 pasien (42\%) dengan tingkat risiko rendah, 27 pasien (27\%) dengan risiko sedang, dan 31 pasien (31\%) dengan risiko tinggi terkena penyakit kardiovaskuler aterosklerotik 10 tahun kedepan. Simpulan: Pada studi ini, persentase tertinggi ialah pasien dengan tingkat risiko rendah terjadinya penyakit kardiovaskuler aterosklerotik, diikuti tingkat risiko tinggi dan risiko sedang.
\end{abstract}

Kata kunci: ASCVD, Framingham Risk Score, tingkat risiko penyakit kardiovaskuler aterosklerotik 
Penyakit kardiovaskuler aterosklerotik adalah penyakit yang disebabkan oleh adanya timbunan plak pada dinding arteri sehingga menyebabkan gangguan fungsional, anatomis serta sistem hemodinamis jantung dan pembuluh darah. ${ }^{1,2}$ Secara global untuk penyakit tidak menular penyebab kematian nomor satu setiap tahunnya ialah penyakit kardiovaskuler. ${ }^{3}$ Sekitar 17,5 juta orang di dunia meninggal kerena penyakit kardiovaskuler dan merupakan $31 \%$ penyebab kematian di seluruh dunia. ${ }^{4}$

Prevalensi penyakit jantung coroner (PJK) berdasarkan pernah didiagnosis dokter di Indonesia sebesar $0,5 \%$ dan berdasarkan diagnosis dokter atau gejala sebesar $1,5 \%$. Prevalensi gagal jantung berdasarkan pernah didiagno-sis dokter di Indonesia sebesar $0,13 \%$, dan berdasarkan diagnosis dokter atau gejala sebesar $0,3 \%$. Prevalensi stroke di Indonesia berdasarkan diagnosis tenaga kesehatan sebesar 7,0 per mil dan yang berdasarkan diagnosis tenaga kesehatan atau gejala sebesar 12,1 per mil. Jadi, sebanyak $57,9 \%$ penyakit stroke telah terdiagnosis oleh tenaga kesehatan. ${ }^{3}$

Terdapat berbagai faktor risiko untuk terjadinya penyakit kardiovaskuler yaitu faktor risiko yang tidak dapat dimodifikasi (usia, jenis kelamin dan riwayat keluarga), dan faktor risiko yang dapat dimodifikasi (peningkatan kadar lipid serum, hipertensi, merokok, diabetes melitus, aktifitas fisik kurang, stres psikososial, obesitas dan peningkatan kadar homosistein). ${ }^{5}$

Pengetahuan tentang faktor risiko penyebab penyakit kardiovaskular sangat penting dalam upaya pencegahan. Tindakan pencegahan dapat dilakukan oleh mereka yang sama sekali belum memiliki faktor risiko maupun juga bagi mereka yang telah memiliki faktor risiko. Dalam hal ini dapat dilakukan pencegahan primer yang bertujuan untuk meningkatkan kesadaran pasien dan menurunkan faktor risiko. ${ }^{5}$

Bagi mereka yang sudah memiliki faktor risiko namun belum pernah mengalami penyakit kardiovaskuler dalam hal ini pasien yang asimtomatik, pencegahan dini sangat diperlukan. Salah satu bentuk pencegahan dini yang dapat dilakukan yaitu dengan memrediksi risiko penyakit kardiovaskuler kedepan. Terdapat beberapa cara untuk melakukan penilaian faktor risiko. Yang paling umum digunakan ialah memakai skor risiko Framingham (Framingham Risk Score) dan di negara Eropa digunakan Systematic COronary Risk Estimation (SCORE). Hasilnya ialah kalkulasi risiko terjadinya penyakit kardiovaskuler aterosklerotik 10 tahun mendatang. ${ }^{7}$

Dalam penelitian ini digunakan metode perhitungan Framingham Risk Score (FRS). Framingham Risk Score adalah salah satu perhitungan untuk mengetahui faktor risiko klasik penyakit kardiovaskuler seperti usia, jenis kelamin, hipertensi, diabetes mellitus (DM), merokok, obesitas, aktivitas fisik dan kadar kolesterol dalam darah. ${ }^{6}$

\section{METODE PENEITIAN}

Penelitian ini bertujuan untuk mendeskripsikan tingkat risiko terjadinya penyakit kardiovaskuler aterosklerotik dengan menggunakan Framinghan Risk Score. Jenis penelitian yang dilakukan ialah deskriptif observasional dengan desain potong lintang. Penelitian dilakukan di Poliklinik Penyakit Dalam RSUP Prof. Dr. R. D. Kandou Manado. Sampel penelitian ialah pasien yang berobat di Poliklinik Penyakit Dalam RSUP Prof. Dr. R. D. Kandou Manado periode September Oktober 2017, diambil dengan menggunakan teknik consecutive sampling. Kriteria inklusi ialah pasien yang berobat di Poliklinik Penyakit Dalam periode September-Oktober 2017, berusia >30 tahun, memiliki data rekam medik lengkap (usia, jenis kelamin, kadar kolestrol total, kadar HDL, tekanan darah, riwayat DM dan kebiasaan merokok). Kriteria eksklusi ialah pasien yang terdiagnosis penyakit kardiovaskuler aterosklerotik.

Penelitian ini menggunakan data rekam medik pasien. Data yang terkumpul dimasukkan ke dalam tabel FRS, dilakukan penghitungan tingkat risiko, kemudian diolah dan diklasifikasikan berdasarkan setiap variabel dalam FRS menggunakan SPSS. 


\section{HASIL DAN BAHASAN}

Total populasi pasien yang berobat di Poliklinik Penyakit Dalam RSUP Prof. Dr. R. D. Kandou Manado yaitu sebanyak 1.712 pasien dan diambil 100 orang pasien yang memenuhi kriteria inklusi dan ekslusi.

\section{Prediksi tingkat risiko 10 tahun kedepan penyakit kardiovaskuler aterosklerotik berdasarkan FRS}

Penelitian ini menggunakan penghitungan prediksi tingkat risiko penyakit kardiovaskuler aterosklerotik dalam 10 tahun kedepan dengan FRS. Didapatkan kebanyakan pasien di Poliklinik Penyakit Dalam RSUP Prof. Dr. R. D. Kandou Manado periode September- Oktober 2017 memiliki tingkat risiko rendah, yaitu 42 orang (42\%) dari 100 orang pasien.

Tabel 1. Prediksi tingkat risiko 10 tahun ke depan penyakit kardiovaskuler aterosklerotik

\begin{tabular}{ccc}
\hline Tingkat risiko & $\mathbf{N}$ & $\mathbf{\%}$ \\
\hline Rendah & 42 & 42 \\
Sedang & 27 & 27 \\
Tinggi & 31 & 31 \\
Total & 100 & 100 \\
\hline
\end{tabular}

Berdasarkan jenis kelamin, diperoleh tingkat risiko tinggi terkena penyakit kardiovaskuler ateroklerotik 10 tahun kedepan yaitu laki-laki sebanyak 20 orang $(57,1 \%)$. Pada penelitian ini umumnya perempuan memiliki risiko rendah yaitu 33 $(50,8 \%)$ dari total 65 orang. Hal ini sesuai dengan pernyataan Brown yang menyatakan bahwa risiko aterosklerosis koroner lebih besar pada laki-laki dari pada perempuan.
Perempuan agak lebih resisten terhadap penyakit ini sampai usia setelah menopause kemudian menjadi sama rentannya seperti pada laki-laki. ${ }^{5}$

Berdasarkan usia, terlihat bahwa usia di bawah atau sama dengan 45 tahun kebanyakan memiliki risiko rendah yaitu 19 orang $(82,6 \%)$ dan tidak ada yang memiliki risiko tinggi terkena penyakit kardiovaskuler aterosklerotik 10 tahun kedepan. Usia diatas 45 tahun kebanyakan memiki risiko tinggi terkena penyakit kardiovaskuler aterosklerotik yaitu sebanyak 31 orang $(40,3 \%)$, selain itu pasien yang berisiko sedang dan rendah masing-masing ada 23 orang $(29,9 \%)$ (Tabel 3). Hal ini sejalan dengan penelitian yang dilakukan oleh Zarahwardani, yang menyatakan bahwa umur merupakan faktor risiko PJK dimana penambahan usia akan meningkatkan risiko terjadinya PJK. ${ }^{9}$ Semakin tua umur seseorang, maka semakin besar kemungkinan timbulnya plak ateroma yang menempel di dinding dan menyebabkan terganggunya aliran darah. ${ }^{9}$

Pada Tabel 4 dapat dilihat kebanyakan dari pasien yang berisiko rendah terkena penyakit kardiovaskuler aterosklerotik ialah yang memiliki kadar HDL 50-60 mg/dL yaitu sebanyak 12 orang $(54,5 \%)$. Pasien yang memiliki risiko tinggi terkena penyakit kardiovaskuler aterosklerotik kebanyakan memiliki kadar HDL 35-45 mg/dL yaitu sebanyak 12 orang $(42,9 \%)$. Hal ini sesuai dengan teori yang menyatakan bahwa kadar HDL yang tinggi berhubungan dengan rendahnya risiko aterosklerosis. ${ }^{13}$

Tabel 2. Distribusi tingkat risiko berdasarkan jenis kelamin

\begin{tabular}{cccccc}
\hline \multirow{2}{*}{$\begin{array}{c}\text { Jenis } \\
\text { kelamin }\end{array}$} & & \multicolumn{3}{c}{ Tingkat risiko } & \multirow{2}{*}{ Total } \\
\cline { 3 - 5 } & & Rendah & Sedang & Tinggi & \\
\hline \multirow{2}{*}{ Laki-Laki } & $\mathrm{N}$ & 9 & 6 & 20 & 35 \\
& $\%$ & 25,7 & 17,1 & 57,1 & 100 \\
Perempuan & $\mathrm{N}$ & 33 & 21 & 11 & 65 \\
& $\%$ & 50,8 & 32,3 & 16,9 & 100 \\
Total & & 42 & 27 & 31 & 100 \\
$\%$ & & 42 & 27 & 31 & 100 \\
\hline
\end{tabular}


Tabel 3. Distribusi tingkat risiko berdasarkan usia

\begin{tabular}{|c|c|c|c|c|c|}
\hline \multirow{2}{*}{\multicolumn{2}{|c|}{ Usia }} & \multicolumn{3}{|c|}{ Tingkat risiko } & \multirow{2}{*}{ Total } \\
\hline & & Rendah & Sedang & Tinggi & \\
\hline \multirow{2}{*}{$\leq 45$} & $\mathbf{N}$ & 19 & 4 & 0 & 23 \\
\hline & $\%$ & 82,6 & 17,4 & 0 & 100 \\
\hline \multirow{2}{*}{$>45$} & $\mathbf{N}$ & 23 & 23 & 31 & 77 \\
\hline & $\%$ & 29,9 & 29,9 & 40,3 & 100 \\
\hline \multicolumn{2}{|c|}{ Total } & 82 & 42 & 27 & 31 \\
\hline \multicolumn{2}{|c|}{$\%$} & 41 & 42 & 27 & 31 \\
\hline
\end{tabular}

Tabel 4. Distribusi tingkat risiko berdasarkan kadar high density lipoprotein (LDL)

\begin{tabular}{|c|c|c|c|c|c|}
\hline \multirow{2}{*}{\multicolumn{2}{|c|}{$\underset{(\mathbf{m g} / \mathbf{d L})}{\text { Kadar HDL }}$}} & \multicolumn{3}{|c|}{ Tingkat risiko } & \multirow{3}{*}{$\begin{array}{c}\text { Total } \\
13\end{array}$} \\
\hline & & \multirow{2}{*}{$\begin{array}{c}\text { Rendah } \\
6\end{array}$} & \multirow{2}{*}{$\begin{array}{c}\text { Sedang } \\
6\end{array}$} & \multirow{2}{*}{$\begin{array}{c}\text { Tinggi } \\
1\end{array}$} & \\
\hline & $\mathbf{N}$ & & & & \\
\hline$>60$ & $\%$ & 46,2 & 46,2 & 7,7 & 100 \\
\hline \multirow{2}{*}{$50-60$} & $\mathbf{N}$ & 12 & 4 & 6 & 22 \\
\hline & $\%$ & 54,5 & 18,2 & 27,3 & 100 \\
\hline \multirow{2}{*}{$45-50$} & $\mathbf{N}$ & 6 & 2 & 1 & 9 \\
\hline & $\%$ & 66,7 & 22,2 & 11,1 & 100 \\
\hline \multirow{2}{*}{$35-45$} & $\mathbf{N}$ & 7 & 9 & 12 & 28 \\
\hline & $\%$ & 25 & 32.1 & 42.9 & 100 \\
\hline \multirow{2}{*}{$<35$} & $\mathbf{N}$ & 11 & 6 & 11 & 28 \\
\hline & $\%$ & 39,3 & 21,4 & 39,3 & 100 \\
\hline \multirow{2}{*}{ Total } & $\mathbf{N}$ & 42 & 27 & 31 & 100 \\
\hline & $\%$ & 42 & 27 & 31 & 100 \\
\hline
\end{tabular}

Tabel 5 memperlihatkan bahwa kebanyakan pasien yang berisiko rendah terkena penyakit kardiovaskuler aterosklerotik 10 tahun kedepan ialah yang memiliki kadar kolesterol total 160-199 $\mathrm{mg} / \mathrm{dL}$ yaitu sebanyak 20 orang $(50 \%)$. Kelompok pasien yang memiliki kadar kolesterol total $\geq 280 \mathrm{mg} / \mathrm{dL}$ sebanyak 3 orang $(50 \%)$ yang berisiko tinggi terkena penyakit kardiovaskuler aterosklerotik dari total 6 orang dengan kadar kolesterol total yang sama. Penelitian yang dilakukan oleh Zarahwardani ${ }^{9}$ menyatakan bahwa kadar kolesterol total dapat meningkatkan risiko empat kali lipat terjadinya PJK.

Tabel 6 memperlihatkan bahwa sebanyak $24(70,6 \%)$ dari total 34 pasien yang memiliki tekanan darah sistol $<120 \mathrm{mmHg}$ berisiko rendah terkena penyakit kardiovaskuler aterosklerotik 10 tahun ke depan. Pada pasien dengan tekanan darah sistol $\geq 160 \mathrm{mmHg}$, tidak ditemukan adanya pasien yang berisiko rendah dan sedang, tetapi yang berisiko tinggi ada 4 orang $(100 \%)$. Dengan demikian, hal ini sesuai dengan penelitian Lannywati ${ }^{10}$ yang menyatakan bahwa responden dengan hipertensi berisiko mengalami PJK 10,09 kali dibandingkan dengan yang tidak hipertensi.

Tabel 7 menunjukkn bahwa terdapat 14 pasien dengan kebiasaan merokok dan yang memiliki risiko tinggi terkena penyakit kardiovaskuler aterosklerotik ialah 8 orang $(57,1 \%)$ sedangkan yang memiliki risiko rendah hanya 1 orang $(7,1 \%)$. Penelitian yang dilakukan Lubna ${ }^{11}$ menyatakan bahwa merokok sigaret dapat memberikan pengaruh buruk terhadap kesehatan sistem kardiovaskuler walaupun dalam paparan rendah. Kandungan dalam rokok seeperti karbon monoksida akan membuat hipoksia jaringan arteri yang menyebabkan disfungsi endotel. $^{12}$ 
Emor, Panda, Pangemanan: Prediksi tingkat risiko penyakit kardiovaskuler ...

Tabel 5. Distribusi tingkat risiko berdasarkan kadar kolesterol total

\begin{tabular}{|c|c|c|c|c|c|}
\hline \multirow{2}{*}{\multicolumn{2}{|c|}{$\begin{array}{c}\text { Kadar kolesterol } \\
\text { total }(\mathbf{m g} / \mathbf{d L})\end{array}$}} & \multicolumn{3}{|c|}{ Tingkat risiko } & \multirow{3}{*}{$\begin{array}{c}\text { Total } \\
27\end{array}$} \\
\hline & & \multirow{2}{*}{$\begin{array}{r}\text { Rendah } \\
14\end{array}$} & \multirow{2}{*}{$\frac{\text { Sedang }}{3}$} & \multirow{2}{*}{$\begin{array}{r}\text { Tinggi } \\
10\end{array}$} & \\
\hline & $\mathbf{N}$ & & & & \\
\hline$<160$ & $\%$ & 51,9 & 11,1 & 37 & 100 \\
\hline \multirow{2}{*}{ 160-199 } & $\mathbf{N}$ & 20 & 11 & 9 & 40 \\
\hline & $\%$ & 50 & 27,5 & 22,5 & 100 \\
\hline \multirow{2}{*}{ 200-239 } & $\mathbf{N}$ & 4 & 10 & 6 & 20 \\
\hline & $\%$ & 20 & 50 & 30 & 100 \\
\hline \multirow{2}{*}{ 240-279 } & $\mathbf{N}$ & 1 & 3 & 3 & 7 \\
\hline & $\%$ & 14,3 & 42,9 & 42,9 & 100 \\
\hline \multirow{2}{*}{$\geq \mathbf{2 8 0}$} & $\mathbf{N}$ & 3 & 0 & 3 & 6 \\
\hline & $\%$ & 50 & 0 & 50 & 100 \\
\hline \multirow{2}{*}{ Total } & $\mathbf{N}$ & 42 & 27 & 31 & 100 \\
\hline & $\%$ & 42 & 27 & 31 & 100 \\
\hline
\end{tabular}

Tabel 6. Distribusi tingkat risiko berdasarkan tekanan darah sistol

\begin{tabular}{|c|c|c|c|c|c|}
\hline \multirow{2}{*}{\multicolumn{2}{|c|}{$\begin{array}{c}\text { Tekanan Darah } \\
\text { Sistol (mmHg) }\end{array}$}} & \multicolumn{3}{|c|}{ Tingkat risiko } & \multirow{3}{*}{$\begin{array}{c}\text { Total } \\
34\end{array}$} \\
\hline & & \multirow{2}{*}{$\begin{array}{c}\text { Rendah } \\
24\end{array}$} & \multirow{2}{*}{$\begin{array}{c}\text { Sedang } \\
4\end{array}$} & \multirow{2}{*}{$\begin{array}{c}\text { Tinggi } \\
6\end{array}$} & \\
\hline & $\mathbf{N}$ & & & & \\
\hline$<120$ & $\%$ & 70,6 & 11,8 & 17,6 & 100 \\
\hline \multirow{2}{*}{$120-129$} & $\mathbf{N}$ & 10 & 7 & 5 & 22 \\
\hline & $\%$ & 45,5 & 31,8 & 22,7 & 100 \\
\hline \multirow{2}{*}{ 130-139 } & $\mathbf{N}$ & 6 & 5 & 6 & 17 \\
\hline & $\%$ & 35,3 & 29,4 & 35,3 & 100 \\
\hline \multirow{2}{*}{$140-149$} & $\mathbf{N}$ & 1 & 9 & 4 & 14 \\
\hline & $\%$ & 7,1 & 64,3 & 28,6 & 100 \\
\hline \multirow{2}{*}{$150-159$} & $\mathbf{N}$ & 1 & 2 & 6 & 9 \\
\hline & $\%$ & 11,1 & 22,2 & 66,7 & 100 \\
\hline \multirow{2}{*}{$\geq 160$} & $\mathbf{N}$ & 0 & 0 & 4 & 4 \\
\hline & $\%$ & 0 & 0 & 100 & 100 \\
\hline \multirow{2}{*}{ Total } & $\mathbf{N}$ & 42 & 27 & 31 & 100 \\
\hline & $\%$ & 42 & 27 & 31 & 100 \\
\hline
\end{tabular}

Tabel 7. Distribusi tingkat risiko berdasarkan kebiasaan merokok

\begin{tabular}{|c|c|c|c|c|c|}
\hline \multirow{2}{*}{\multicolumn{2}{|c|}{$\begin{array}{c}\text { Kebiasaan } \\
\text { merokok }\end{array}$}} & \multicolumn{3}{|c|}{ Tingkat risiko } & \multirow{3}{*}{$\begin{array}{c}\text { Total } \\
14\end{array}$} \\
\hline & & \multirow{2}{*}{$\begin{array}{c}\text { Rendah } \\
1\end{array}$} & \multirow{2}{*}{$\begin{array}{c}\text { Sedang } \\
5\end{array}$} & \multirow{2}{*}{$\begin{array}{c}\text { Tinggi } \\
8\end{array}$} & \\
\hline Y & $\mathbf{N}$ & & & & \\
\hline Ya & $\%$ & 7,1 & 35,7 & 57,1 & 100 \\
\hline \multirow{2}{*}{ Tidak } & $\mathbf{N}$ & 41 & 22 & 23 & 86 \\
\hline & $\%$ & 47,7 & 25,6 & 26,7 & 100 \\
\hline \multirow{2}{*}{ Total } & $\mathbf{N}$ & 42 & 27 & 31 & 100 \\
\hline & $\%$ & 42 & 27 & 31 & 100 \\
\hline
\end{tabular}

Tabel 8 memperlihatkan penyebaran tingkat risiko berdasarkan penyakit DM. Terdapat 18 orang pasien $(48,6 \%)$ yang memiliki risiko tinggi terkena penyakit kardiovaskuler aterosklerotik dan hanya 9 orang $(24,3 \%)$ yang memiliki risiko rendah. 
Bagi pasien yang tidak menyandang DM, terdapat sebanyak 33 orang $(52,4 \%)$ yang berisiko rendah terkena penyakit kardiovaskuler aterosklerotik dan hanya 13 orang $(20,6 \%)$ yang berisiko tinggi terkena penyakit kardiovaskuler aterosklerotik 10 tahun kedepan.

Penelitian yang dilakukan oleh Nadzir $^{12}$ menyatakan bahwa DM dapat meningkatkan risiko PJK karena pada penyandang DM dengan resistensi insulin terjadi peningkatan $c$-reactive protein yang merupakan mediator inflamasi. Zat ini nantinya akan menarik kolesterol LDL dan bergabung dengan makrofag membentuk foam cell yang merupakan awal proses aterosklerosis.

Tabel 8. Distribusi tingkat risiko berdasarkan diabetes melitus

\begin{tabular}{lccccc}
\hline \multirow{2}{*}{ Diabetes melitus } & \multicolumn{3}{c}{ Tingkat risiko } & \multirow{2}{*}{ Total } \\
\cline { 3 - 5 } & & Rendah & Sedang & Tinggi & \\
\hline \multirow{2}{*}{ Ya } & N & 9 & 10 & 18 & 37 \\
\multirow{4}{*}{ Tidak } & \% & 24,3 & 27 & 48,6 & 100 \\
& N & 33 & 17 & 13 & 63 \\
\multirow{2}{*}{ Total } & \% & 52,4 & 27 & 20,6 & 100 \\
& $\mathbf{N}$ & 42 & 27 & 31 & 100 \\
& \% & 42 & 27 & 31 & 100 \\
\hline
\end{tabular}

\section{SIMPULAN}

Dari hasil penelitian terhadap pasien yang berobat di Poliklinik Penyakit Dalam RSUP Prof. Dr. R. D. Kandou Manado periode September-Oktober 2017 dengan menggunakan Framinghan Risk Score didapatkan persentase tertinggi ialah pasien dengan tingkat risiko rendah terjadinya penyakit kardiovaskuler aterosklerotik, diikuti tingkat risiko tinggi dan risiko sedang.

\section{SARAN}

1. Dengan diketahuinya tingkat risiko 10 tahun kedepan penyakit kardiovaskuler ateroklerotik ini pada pasien di Poliklinik Penyakit Dalam Periode September Oktober 2017, diharapkan pasien dapat melakukan pencegahan untuk mengurangi perburukan penyakit kedepan.

2. Pemberian edukasi ataupun promosi kesehatan akan sangat berperan dalam pencegahan bagi mereka yang belum terkena penyakit kardiovaskuler aterosklerotik khususnya pasien dengan tingkat risiko rendah, sedang dan berat.

3. Diharapkan untuk penelitian selanjutnya lebih memperbanyak populasi dan dapat menganalisis faktor-faktor risiko yang berhubungan dengan penyakit kardiovaskuler aterosklerotik ini.

\section{DAFTAR PUSTAKA}

1. Barnes K, Theodore B, Fine A, Goldstone $A$, Groeneweg M, Haugen S, et al. ASCVD Primary Prevention Guideline. Kaiser Foundation Health Plan of Washington, 2016.

2. Badan Penelitian dan Pengembangan Kesehatan Kementerian Kesehatan RI. Riset Kesehatan Dasar (Riskesdas) 2013. Jakarta, 2013.

3. Kementrian dan Kesehatan RI. Situasi Kesehatan Jantung. Jakarta, 2014.

4. World Health Organization. Cardiovascular Disease 2017 [Internet]. [cited 2017 Agustus 2]. Available from: http://www.who.int/cardiovascular_dis ease/en/

5. Brown CT. Penyakit aterosklerotik koroner. In: Pendit BU, Hartanto H, Wulansari P, Mahanani DA, editors. Patofisiologi Konsep Klinis Proses-proses Penyakit (6th ed). Jakarta: EGC, 2013; p. 576612.

6. Indrawati L. Hubungan antara pengetahuan, sikap, persepsi, motivasi, dukungan keluarga dan sumber informasi pasien 
penyakit jantung koroner dengan tindakan pencegahan sekunder faktor resiko. Jurnal ilmiah WIDYA. 2014;2:30-36.

7. Adi PR. Pencegahan dan penatalaksanaan aterosklerosis. In: Setyati S, Alwi I, Sudoyo AW, Simadibrata MK, Setiyohadi B, Syam AF, editors. Ilmu Penyakit Dalam Jilid 2 (6th ed). Jakarta: Internal Publishing, 2014; p. 1425-35.

8. de Ruijter W, Westendorp RG, Assendelft WJ, den Elzen WP, de Craen AJ, le Cessie S, et al. Use of Framingham risk score and biomarkers to predict cardiovascular mortality in older people; population based observational cohort study. BMJ. 2009;388:a3083.

9. Zahrawardani D, Herlambang KS, Anggraheny HD. Analisis faktor ririko kejadian PJK di RSUP Dr. Kariadi
Semarang. Jurnal Kedokteran Muhammadiyah. 2013;2:13-20.

10. Ghani L, Susilawati MD, Novriani $H$. Faktor resiko dominan penyakit jantung koroner di Indonesia. Buletin Penelitian Kesehatan. 2016;44:153-64.

11. Lubna SR. Predicting coronary heart disease through risk factor categories. ASEE 2014 Zone I Conference. 2014.

12. Nadzir M, Suryono, Prasetyo A. Prediksi penyakit jantung koroner pada PNS yang melakukan medical checkup di RSUD dr Soebandi Jember dengan metode Framingham Risk Score [Artikel Ilmiah Hasil Penelitian Mahasiswa]. Jember: Fakultas Kedokteran Universitas Jember; 2015.

13. Kumar V, Abbas AK, Aster JC. Buku Ajar Patologi Robbins (9th ed). Singapore: Elsevier Saunders, 2015; p. 321-57. 